http://jmscr.igmpublication.org/home/

ISSN (e)-2347-176x ISSN (p) 2455-0450

crossref DOI: https://dx.doi.org/10.18535/jmscr/v8i3.04

Journal Of Medical Science And Clinical Research

\title{
A Comparative Study of Thyroid Profile in Individuals with and Without Metabolic Syndrome
}

Authors

\author{
Dr Subhasish Deb, Dr Amit Sarkar, Dr Somnath Dasgupta, \\ Dr Ashish P Dudhe, Dr Agnibha Dutta
}

Burdwan Medical College and Hospital, P.O. Burdwan, Pin - 713104, District - East Burdwan, West Bengal, India

Corresponding Author

Dr Amit Sarkar

\begin{abstract}
Metabolic syndrome is increasingly recognised as emerging threats to health of human race. Thyroid hormones up regulate metabolic pathways relevant to resting energy expenditure. Obesity causes alteration in thyroid function tests. We compared the thyroid profiles of individuals with and without Metabolic Syndrome and assessed the possibility of obesity influencing the results. This is a cross sectional study which includes 200 patients above the age of 18 years attending the outpatient department of our institution from January 2015 to August 2016. They were divided into four groups where group 1 consists of patients with Metabolic syndrome and obesity, group 2 with Metabolic Syndrome without obesity, group 3 without Metabolic syndrome but obese and group 4 without Metabolic syndrome and non obese. The NCEP ATP III criteria was used for assessing Metabolic syndrome and revised consensus guidelines for Asian Indians was chosen to determine the Body Mass Index (BMI) for obesity. TSH, T4, T3 were measured as indicators of thyroid function. The difference in mean TSH levels between individuals with Metabolic Syndrome $(3.84 \pm 2.44 \mathrm{uIU} / \mathrm{L})$ and without Metabolic Syndrome $(2.10 \pm 1.70 \mathrm{uIU} / \mathrm{L})$ was statistically significant ( $p=\leq 0.05$ ) while the mean T4 and T3 levels were comparable. Amongst individuals with metabolic syndrome, difference of mean TSH between obese and non-obese group was not significant $(p=0.984)$. Individuals with Metabolic syndrome have a higher TSH level but normal T3 and T4 levels. This rise in TSH is independent of obesity.
\end{abstract}

Keywords: Metabolic syndrome, Thyroid profile.

\section{Introduction}

Metabolic syndrome is now being increasingly recognised as an emerging threat which will invade desktops of public health policy planners in the decades to come. Metabolic syndrome is a constellation of many abnormalities or disease. The major features of metabolic syndrome include central obesity, hypertriglyceridemia, low high density lipoprotein cholesterol, hyperglycemia and hypertension ${ }^{1}$. The prevalence of metabolic syndrome in western world is about 20$30 \%{ }^{2,3,4}$. By National Cholesterol Education Programme Adult Treatment Panel III (NCEP ATP III) criterion, $41.1 \%$ of Asian Indian were suffering from metabolic syndrome, whereas the 
prevalence of metabolic syndrome was $11.2 \%$ in Chennai urban population ${ }^{5,6}$. The Jaipur heart study have reported that prevalence of metabolic syndrome in urban Indian population was $18.4 \%$ in men , $30.9 \%$ in women and $24.9 \%$ overall $^{7}$. Obesity, a main component of metabolic syndrome occurs due to increased energy intake, decreased energy expenditure or a combination of both, thus leading to positive energy balance. Thyroid hormones up regulate metabolic pathways relevant to resting energy expenditure. Obesity causes alteration in thyroid function tests. There are studies which showed subclinical thyroid dysfunction and even thyroid stimulating hormone within high normal range can be related to metabolic syndrome and its components ${ }^{8,9}$. This study is intended to compare thyroid function in patients with and without metabolic syndrome and asses the possibility of obesity influencing the results.

\section{Materials and Method}

Study area and period: This cross-sectional study was conducted at our institution from January 2015 to August 2016. This institution is tertiary referral centre for patients of neighbouring seven districts and part of neighbouring State. All participants were provided with written informed consent and the study protocol was approved by the Ethical Committee of the institution .

Study population: The study subjects included 200 patients with 100 having metabolic syndrome and 50 patients out of these 100 patients were obese. The remaining 100 patients did not have metabolic syndrome and this group was further subdivided into groups of 50 patients with or without obesity each. All subjects were divided into four groups for statistical comparison - 1. Metabolic syndrome with obesity (Mets Obese); 2. Metabolic syndrome without obesity ( Mets non-Obese); 3. Non-metabolic syndrome with obesity (Non- mets
Obese); 4.Non- metabolic syndrome without obesity (Non- Mets non -Obese)

People above the age of 18 years attending General Medicine outpatient department of our institution were included in this study. The National Cholesterol Education Programme Adult Treatment Panel III (NCEP ATP III) criteria was used for identifying individuals with metabolic syndrome. Three or more out of five criterion was taken to define metabolic syndrome: 1 . Waist circumference- Men $>40$ inches, women $>35$ inches; 2 . Triglyceride- $\geq 150 \mathrm{mg} / \mathrm{dl}$ or on treatment for hypertriglyceridemia; 3. HDL Cholesterol- men $<40 \mathrm{mg} / \mathrm{dl}$, women $<50 \mathrm{mg} / \mathrm{dl}$ or on treatment for low HDL Cholesterol ; 4. Blood pressure $>130 / 85 \mathrm{~mm}$ of $\mathrm{Hg}$ or on treatment for hypertension and 5. Fasting glucose $\geq 100 \mathrm{mg} / \mathrm{dl}$ or on treatment for diabetes mellitus ${ }^{10}$. The criteria for obesity was taken as per revised consensus guidelines for Asian Indians with Body Mass Index $(B M I) \geq 25 \mathrm{~kg} / \mathrm{m}^{2}$ 11. Those excluded consisted of participants having a personal history of thyroid disease and have been taking thyroxin, antithyroid drugs or radioiodine for treatment ; taking medication affecting thyroid function such as glucocorticoids, antiepileptics and contraceptive drugs ; pregnant woman or within first year of post partum; renal and liver disorders.

Data Collection: Consecutive samples taken till desired sample size reached. All subjects underwent careful interview with questionnaire using a structured Performa. We abstracted general information such as name, age, gender, educational qualification, profession, history of smoking and drinking, personal and family history of thyroid disease, diabetes, hypertension and dyslipidaemia. The relevant clinical and investigative data were recorded. Patient particulars including height, weight, body mass index and waist circumference were recorded. All the patients were asked to rest at least 30 minutes and then blood pressure of their right arm was measured twice with a sphygmomanometer with the participants in a sitting position. There 
was a 5-min interval between the two measurements for each participant, and the mean value of the two measurements was used. All blood samples were taken in empty stomach. Blood glucose was measured by glucose oxidase method. Lipids were measured by Hitachi 704 analyser. Acuu Lite VAST CLIA Kits was used for TSH (Thyroid stimulating hormone), T3 (Triiodothyronine) and T4 (Thyroxin) measurements.

Statistical Analysis: The analysis was performed using SPSS 20 software. The unpaired student $t$ test was used to find a relation between mean TSH levels in those with and without metabolic syndrome and amongst four groups with each other.

\section{Result}

On comparison of different clinical data amongst patients of metabolic and non- metabolic syndrome BMI, waist circumferences and systolic blood pressure were significantly different. But diastolic blood pressure was comparable (Table 1). The mean blood fasting and post prandial sugar, triglyceride, HDL cholesterol were significantly different amongst individuals with metabolic and non-metabolic syndrome. The difference in mean TSH levels in individuals with Metabolic Syndrome (3.84 \pm 2.44 $\mu \mathrm{IU} / \mathrm{L})$ and without Metabolic Syndrome (2.10 \pm $1.76 \mu \mathrm{IU} / \mathrm{L})$ was statistically significant $(\mathrm{p}=\leq 0.05)$ while the mean T4 and T3 levels were comparable (Table 2). Difference of mean TSH in groups Mets obese $(3.86 \pm 2.62)$ and Mets non-obese $(3.87 \pm 2.27)$ was not significant $(\mathrm{p}=0.984)$. Similar results $(\mathrm{p}=0.791)$ was found in mean TSH in groups Non-mets obese $(2.14 \pm 1.94)$ and Non-mets non-obese $(2.04 \pm 1.43)$ was (Table 3$)$.

Table 1: Comparison of different demographic, physical and clinical data in subjects with and without metabolic syndrome.

\begin{tabular}{|c|c|c|c|}
\hline Variables & $\begin{array}{l}\text { With Metabolic } \\
\text { syndrome }\end{array}$ & $\begin{array}{c}\text { Without Metabolic } \\
\text { syndrome }\end{array}$ & p-value \\
\hline Age $($ years) $($ mean \pm SD $)$ & $56.83 \pm 12.42$ & $52.99 \pm 14.60$ & 0.047 \\
\hline \multirow{2}{*}{$\begin{array}{r}\text { Sex(number- \%) male } \\
\text { Female }\end{array}$} & 51 & 57 & \\
\hline & 49 & 43 & \\
\hline BMI $\left(\mathrm{Kg} / \mathrm{m}^{2}\right)($ mean $\pm \mathrm{SD})$ & $24.11 \pm 4.41$ & $22.35 \pm 4.73$ & 0.007 \\
\hline $\begin{array}{l}\text { Waist cicumferences }(\mathrm{cm}) \\
(\text { mean } \pm \text { SD) }\end{array}$ & $87.74 \pm 11.77$ & $84.52 \pm 9.88$ & 0.037 \\
\hline $\begin{array}{l}\text { Systolic BP(mm of Hg) } \\
(\text { mean } \pm \text { SD) }\end{array}$ & $125.80 \pm 19.99$ & $120.54 \pm 16.17$ & 0.043 \\
\hline $\begin{array}{l}\text { Diastolic } \mathrm{BP}(\mathrm{mm} \text { of } \mathrm{Hg}) \\
(\text { mean } \pm \text { SD })\end{array}$ & $77.86 \pm 9.73$ & $77.20 \pm 6.60$ & 0.575 \\
\hline
\end{tabular}

Table 2 Comparison of different investigative data in subjects with and without metabolic syndrome

\begin{tabular}{|l|c|c|c|}
\hline Variables & $\begin{array}{c}\text { With Metabolic } \\
\text { Syndrome }\end{array}$ & $\begin{array}{c}\text { Without Metabolic } \\
\text { syndrome }\end{array}$ & p-value \\
\hline F Sugar $(\mathrm{mg} / \mathrm{dl})($ mean \pm SD) & $120.47 \pm 41.54$ & $98.41 \pm 16.70$ & $\leq 0.05$ \\
\hline PP Sugar $(\mathrm{mg} / \mathrm{dl})(\mathrm{mean} \pm \mathrm{SD})$ & $190.80 \pm 61.48$ & $146.50 \pm 51.76$ & $\leq 0.05$ \\
\hline Triglyceride $(\mathrm{mg} / \mathrm{dl})(\mathrm{mean} \pm \mathrm{SD})$ & $135.97 \pm 27.26$ & $117.15 \pm 21.07$ & $\leq 0.05$ \\
\hline HDL-Cholesterol $(\mathrm{mg} / \mathrm{dl})(\mathrm{mean} \pm \mathrm{SD})$ & $44.66 \pm 7.22$ & $50.81 \pm 8.50$ & $\leq 0.05$ \\
\hline T3 $($ mean $\pm \mathrm{SD})(\mathrm{ng} / \mathrm{ml})$ & $1.28 \pm 0.65$ & $1.41 \pm 0.64$ & 0.156 \\
\hline T4 $($ mean $\pm \mathrm{SD})(\mu \mathrm{g} / \mathrm{dl})$ & $7.99 \pm 3.11$ & $8.01 \pm 3.54$ & 0.966 \\
\hline TSH $(m e a n \pm S D)(\mu \mathrm{IU} / \mathrm{ml})$ & $3.84 \pm 2.44$ & $2.10 \pm 1.76$ & $\leq 0.05$ \\
\hline
\end{tabular}


Table 3 Comparison of mean TSH level among each other of different study group

\begin{tabular}{|c|c|c|c|c|}
\hline & $\begin{array}{c}\text { TSH level } \\
(\mu \mathrm{IU} / \mathrm{ml})\end{array}$ & & $\begin{array}{c}\text { TSH level } \\
(\mu \mathrm{IU} / \mathrm{ml})\end{array}$ & p-value \\
\hline \multirow{3}{*}{ Mets obes } & \multirow[t]{3}{*}{$3.86 \pm 2.62$} & Mets non-obes & $3.87 \pm 2.27$ & 0.984 \\
\hline & & Non-mets obes & $2.14 \pm 1.94$ & $\leq 0.05$ \\
\hline & & Non-mets non-obes & $2.04 \pm 1.43$ & $\leq 0.05$ \\
\hline \multirow{3}{*}{ Mets non-obes } & \multirow[t]{3}{*}{$3.87 \pm 2.27$} & Mets obes & $3.86 \pm 2.62$ & 0.984 \\
\hline & & Non-mets obes & $2.14 \pm 1.94$ & $\leq 0.05$ \\
\hline & & Non-mets non-obes & $2.04 \pm 1.43$ & $\leq 0.05$ \\
\hline \multirow{3}{*}{ Non-mets obes } & \multirow[t]{3}{*}{$2.14 \pm 1.94$} & Mets obes & $3.86 \pm 2.62$ & $\leq 0.05$ \\
\hline & & Mets non-obes & $3.87 \pm 2.27$ & $\leq 0.05$ \\
\hline & & Non-mets non-obes & $2.04 \pm 1.43$ & 0.791 \\
\hline \multirow{3}{*}{ Non-mets non-obes } & \multirow[t]{3}{*}{$2.04 \pm 1.43$} & Mets obes & $3.86 \pm 2.62$ & $\leq 0.05$ \\
\hline & & Mets non-obes & $3.87 \pm 2.27$ & $\leq 0.05$ \\
\hline & & Non-mets obes & $2.14 \pm 1.94$ & 0.791 \\
\hline
\end{tabular}

Mets obes $=$ Metabolic syndrome with obesity, Mets non-obes = Metabolic syndrome with no obesity,

Non-mets obes $=$ No metabolic syndrome with obesity, Non-mets non - obes $=$ No metabolic syndrome with no obesity .

\section{Discussion}

There is an inconsistency in thyroid function in metabolic syndrome. The rise of TSH with normal T3 and T4 are mostly reported, ${ }^{8,9}$ but the rise in TSH with alteration of T3 without any effect on T4 or increased thyroid hormone levels have also been described in obesity. ${ }^{12,13}$ Ruhla $\mathrm{S}$ et al found that euthyroid subjects with a TSH in the upper normal range (2.5-4.5uIU/L) were more obese, had higher triglycerides and had an increased likeliness of metabolic syndrome. ${ }^{14}$ Lee YK et al found that high normal TSH levels were significantly associated with metabolic syndrome. $^{15}$

These studies have similar findings with that of ours. We found that the mean TSH was a significantly higher in individuals with metabolic syndrome $(3.84 \pm 2.44)$ compared to those without $(2.10 \pm 1.76)$ but T3 and T4 levels were comparable. We further found that this rise in TSH levels among individuals with metabolic syndrome was independent of them being obese as mean TSH of met obese $(3.86 \pm 2.62)$ and met non-obese $(3.87 \pm 2.27)$ were comparable $(\mathrm{p}=0.984)$, so was the mean TSH of non-metsobese $(2.14 \pm 1.94)$ and non-mets non-obese (2.04 \pm 1.43 ) with $\mathrm{p}=0.791$.

The metabolic syndrome is associated with insulin resistance and a hyperinsulinemia is a metabolic consequence. These patients with metabolic syndrome may have a thyroid receptor resistance, similar to insulin resistance resulting in persistent elevated TSH levels.

Studies showed that adipocytes and preadipocytes expressed TSH receptors. TSH binds with this TSH receptors and induces preadipocytes to produce and release adipokines. One of them is leptin which plays a very important role in the onset of metabolic syndrome and cardiovascular disease. ${ }^{16}$

Recently, an experimental study in an animal model has demonstrated that the mutation of alpha isoform of the thyroid hormone receptor caused insulin resistance and thyroid hormone resistance. ${ }^{17}$ In addition, studies investigating thyroid hormone receptors in metabolic syndrome subjects demonstrated a decrease of TSH-R density. $^{18,19}$

Our findings in this study suggests that raised TSH levels in those with metabolic syndrome could be due to associated thyroid receptor resistance similar to insulin resistance. This is supported by the normal T3 and T4 levels . Insulin resistance in hypothyroidism is usually thought to be due to decreased intracellular glucose utilisation and reduced glucose transporter (GLUT 4) translocation. It is also due to decreased glycogen synthesis and reduced glucose oxidation ${ }^{20}$. Administration of TSH to euthyroid patients caused endothelial dysfunction and increased serum level of C- 
reactive protein, TNF- $\alpha$, several indices of oxidative stress and IL -6 , which leads to an increase in the components of metabolic syndrome, thus explaining the relation between increased TSH and metabolic syndrome, ${ }^{21,22}$. The raised TSH could be due to hormones secreted by adipose tissue but our study have shown that this rise in TSH is independent of obesity. Whether metabolic syndrome and thyroid dysfunction is related to common biochemical markers or risk factors are still not known. More studies are needed to determine whether TSH should be routinely done in patients with metabolic syndrome.

\section{Source of support: Nil}

\section{References}

1. Reaven GM: Banting lecture 1988. Role of Insulin Resistance in Human Disease. Diabetes 1988 Dec; 37(12):1595-1607.

2. Meigs JB, Wilson PWF, Nathan DM , D'Agostino RB Sr, Williams K, Haffner SM . Prevalence and Characteristics of the Metabolic Syndrome in the San Antonio Heart and Framingham Offspring Studies. Diabetes 2003 Aug ; 52(8) : 2160-67.

3. Bonora E, Kiechl S, Willeit J, Oberhollenzer F, Egger G , Bonadonna RC, Muggeo M Metabolic syndrome: epidemiology and more extensive phenotypic description. Cross-sectional data from the Bruneck Study. Int J Obes Relat Metab Disord 2003 Oct; 27(10): 1283-89.

4. Salaroli LB, Barbosa GC, Mill JG, Molina MCB . Prevalence of metabolic syndrome in population-based study, Vitória, ESBrazil. Arq Bras Endocrinol Metab 2007 Oct ; 51 (7): 1143-52.

5. Ramachandran A, Snehalatha C, Satyavani K, Sivasankari S, Vijay V. Metabolic syndrome in urban Asian Indian adults -- A population study using modified ATP III criteria . Diabetes Res Clin Pract 2003; 60 (3):199- 204.

6. Mohan V, Shanthirani S, Deepa R , Premalatha G, Sastry NG, Saroja R . Intra-urban differences in the prevalence of the metabolic syndrome in southern India - The Chennai Urban Population Study (CUPS No.4) .Diabet Med 2001 ;18(4):280-87.

7. Gupta R, Deedwania PC, Gupta A, Rastogi S, Panwar RB, Kothari K: Prevalence of metabolic syndrome in an Indian urban population. Int $\mathbf{J}$ Cardiol 2004, 97(2):257-61.

8. Luboshitzky R, Aviv A, Herer P, Lavie L (2002) Risk factors for cardiovascular disease in women with subclinical hypothyroidism. Thyroid $2002 ; 12(5)$ : 421-25.

9. Knudsen N, Laurberg P, Rasmussen LB, Bülow I, Perrild H, Ovesen L, Jørgensen T Small Differences in Thyroid Function May Be Important for Body Mass Index and the Occurrence of Obesity in the Population. J Clin Endocrinol Metab 2005 July 1 ; 90(7): 4019-24

10. Executive Summary of the Third Report of the National Cholesterol Education Program (NCEP) Expert Panel on Detection, Evaluation and Treatment of High Blood Cholesterol in Adults (Adult Treatment Panel III). JAMA 2001; 285(19):2486-97.

11. Mishra A, Chowbey P, Makkar BM, Vikram NK, Wasir JS, Chadha D,Joshi S R,Sadikot S, Gupta R, Gulati S, Munjal YP. Consensus Statement for Diagnosis of Obesity, Abdominal Obesity and the Metabolic Syndrome for Asian Indians and Recommendations for Physical Activity, Medical and Surgical Management. J Assoc Physicians India. 2009 Feb ; 57 : 163-7.

12. Stichel H, I'Allemand D, Gruters A. Thyroid Function and Obesity in Children 
and Adolescents. Horm Res 2000;54 (1):14-19.

13. Kiortsis DN, Durack I, Turpin G. Effects of a low-calorie diet on resting metabolic rate and serum tri-iodothyronine levels in obese children. Eur J Pediatr 1999 May ; 158(6):446-50

14. Ruhla S , Weickert MO , Arafat AM, Osterhoff M, Isken F, Spranger J, Schofl C, Pfeiffer AFH, Mohlig M, A high normal TSH is associated with the metabolic syndrome. Clin Endocrinol (oxf) 2010 March 25 ;72(5):696-701

15. Lee YK, Kim JE, Oh HJ,Park KS, Kim SK,Park SW, Kim MJ,Cho YW . Serum TSH level in Healthy Koreans and the Association of TSH with Serum Lipid Concentration and Metabolic Syndrome. Korean J Intern Med 2011 Dec;26(4):4329

16. Bastemir M , Akin F , Alkis E , Kaptanoglu B . Obesity is associated with increased serum TSH level, independent of thyroid function. Swiss Med Wkly 2007; 137(29-30): 431-4.

17. Liu Y Y, Schultz J J, Brent G A. A Thyroid Hormone Receptor alpha gene mutation (P398H) Is Associated with Visceral Adiposity and Impaired Catecholamine stimulated Lipolysis in Mice. J Biol Chem 2003; 278 (40):3891320.

18. Burman K D , Latham K R , Djuh Y-Y, Smallridge R C, Tseng Y-C L, Lukes Y G, Maunder R, Wartofsky L . Solubilized Nuclear Thyroid Hormone Receptors in Circulating Human Mononuclear Cell. J Clin Endocrinol Metab 1980 ; 51(1) : 10616.
19. Escobar-Morreale H F Obregon M J , Escobar del Ray F, Morreale de Escobar G. Replacement therapy for hypothyroidism with thyroxine alone does not ensure euthyroidism in all tissues, as studied in thyroidectomised rats. J Clin Invest 1995 ; 96(6):2828-38.

20. Maratou E, Hadjidakis DJ, Kollias A et al. Studies of insulin resistance in patients with clinical and subclinical hypothyroidism. Eur J Endocrinol 2009;160(5):785-90.

21. Dardano A, Ghiadoni L, Plantinga Y, Caraccio N, Bemi A, Duranti E, Taddei S, Ferrannini E, Salvetti A, Monzani F . Recombinant Human Thyrotropin Reduces Endothelium- Dependent Vasodilation in Patients Monitored for ifferentiated Thyroid Carcinoma. J Clin Endocrinol Metab 1 October 2006 ; 91(10): 4175-78.

22. Antunes TT, Gagnon A, Chen B, Pacini F, Smith TJ, Sorisky A . Interleukin-6 release from human abdominal adipose cells is regulated by thyroid stimulating hormone: effect of adipocyte differentiation and anatomic depot. Am J Physiol Endocinol Metab 2006 JUN 01;290 (6) :E1140-4. 